American Journal of Biochemistry and Biotechnology 4(3): 255-264, 2008

ISSN 1553-3468

(C) 2008 Science Publications

\title{
Novel Metal Accumulator and Protease Secretor Microbes from East Calcutta Wetland
}

\author{
Sanhita Chowdhury, Madhusmita Mishra, V.K. Adarsh, Anindita Mukherjee, \\ Ashoke Ranjan Thakur and Shaon Ray Chaudhuri \\ Department of Biotechnology, West Bengal University of Technology, \\ BF-142, Sector 1, Salt Lake, Calcutta-700064, India
}

\begin{abstract}
Nine bacterial isolates were screened from different sites of East Calcutta Wetland, an ecosystem located at the eastern fringes of Calcutta. Other than being a biodiversity rich area, the important feature of this system is that it is a natural sewage treatment plant for the city of Calcutta. In addition to daily sewage including solid and soluble wastes, a considerable load of toxic metals are released into the water bodies from industries, tanneries, agriculture, household as well as health sectors. Screening out microbes from such an environment was done keeping in mind their multi functional application. These bacterial isolates were found to produce extracellular protease which is known to have vast applications in the commercial market of enzymes. The key area of this study is exploring the role of these isolates in heavy metal remediation. These isolates were found to tolerate heavy metals like $\mathrm{Ag}, \mathrm{Al}, \mathrm{Cu}, \mathrm{Cr}, \mathrm{Co}, \mathrm{Ni}$ and $\mathrm{Pb}$. Energy Dispersive X Ray Fluorescence (EDXRF) analysis and Transmission Electron Microscopy of the metal treated cells confirm the intracellular accumulation. Moreover, a preliminary demonstration of the effect of metal induced stress on cell surface features was determined by Scanning Electron Microscopy.
\end{abstract}

Key words: East Calcutta Wetland, EDXRF, TEM, SEM, nanoparticle, protease secreting bacteria

\section{INTRODUCTION}

East Calcutta Wetland (ECW) is an example of a model ecosystem where product generation is based on waste recycling. It is rightly called the best example of integrated resource recovery being involved in activities like vegetable farming on garbage dumped fields, wastewater-fed fish cultivation and winter paddy farming using fishpond effluent. These practices generate food of edible quality and employment for local people while maintaining a healthier environment by detoxification of wastes ${ }^{[1,2,3]}$. ECW spanning an area of about 12500 hectare is basically a sewage disposal plant for Calcutta. It receives about 600 million liters of liquid sewage along with 2500 tonnes of garbage on a daily basis. Other than this, there is release of high concentration of toxic heavy metals from industries, tanneries, agriculture as well as health sectors. Many industries, especially electroplating, battery and plastic manufacturing units release heavy metals such as $\mathrm{Cd}$ and $\mathrm{Zn}$ in wastewater ${ }^{[4,5]}$. A high concentration of $\mathrm{Cr}$ comes from tanneries located around this area. Industries dealing with electroplating as well as metal handicraft manufacturing release lot of $\mathrm{Cu}$ into the environment. The source of $\mathrm{Pb}$ is from the battery industries and automobile garages which are there in and around Calcutta. All these are dumped into Bheri (shallow flat bottom sewage fed fishpond) along with the wastewater and thereafter a natural process of purification starts which is a combined effort of vast group of planktons, water hyacinth as well as microbes ${ }^{[6,7]}$. The microbial resource mapping of this site reveals the existence of microbes belonging to 12 main bacterial phyla ${ }^{[8]}$. Presence of microbes like Actinobacteria and Fermicutes indicate the possible bioremediation mechanism operating there. Based on this background study, ECW was selected as the site for screening out potential microbes. During this microbial baseline survey, certain clones showed similarity with Streptococcus macedonicus (95.78-99.63\%), a strain producing extracellular protease $^{[9]}$ and food grade bacteriocine and the growth conditions of the same was used for cultivation of bacterial isolates from different sites of ECW.

Microbes are known to have application in diverse fields starting from health to industry. They can be exploited at a commercial level, one of the means can be the enzymes produced by them. One such enzyme in much demand is protease which covers $60 \%$ of total worldwide sale of enzymes ${ }^{[10]}$. Microorganisms

Corresponding Author: Shaon Raychaudhuri, Department of Biotechnology, West Bengal University of Technology, Calcutta, 700064, India Tel: +91 33 23210731/108 Fax: +91 3323341030 
represent an excellent source of enzymes owing to their broad biochemical diversity and susceptibility to genetic manipulation. Microbial proteases account for approximately $40 \%$ of the total worldwide enzyme sale. Several strains belonging to Pseudomonas sp. as well as Bacillus subtilis are reported to produce extracellular protease ${ }^{[11,12]}$. The main application of this enzyme is in food, pharmaceutics, detergent and leather industry. In leather industry it can replace the conventional method of chemical treatment involving lime, sodium sulphide, salt, solvents, thereby decreasing the use and release of these environmental hazardous products.

The activity of microbes is not only limited to commercial exploitation rather it is now extended to environment management too. Present concern of human society is environmental protection and in turn providing a healthy life to man. There again comes the importance of microbes, in sustenance of the environment. These days microbes have superseded the conventional techniques of remediation ${ }^{[13]}$. Toxic metals like $\mathrm{Pb}, \mathrm{Hg}, \mathrm{Cd}, \mathrm{As}, \mathrm{Cr}$ and $\mathrm{U}$ are released to the environment as a result of human and industrial activities. Though these metals are essential, but after a certain level they become toxic to all life forms. Since heavy metals are increasingly found in microbial habitats, they have evolved several mechanisms to tolerate the presence of heavy metals. These mechanisms include the efflux of metal ions outside the cell, accumulation and complexation of metal ions inside the cell and reduction of the heavy metal ions to a less toxic state ${ }^{[14,15]}$. Microbes play an important role in biogeochemical cycling of metals. Metal accumulating bacteria can be used to remove, concentrate and recover metals from mine tailings and industrial effluents ${ }^{[16]}$. Several aerobic bacteria are reported to accumulate metals like $\mathrm{Ag}, \mathrm{Co}, \mathrm{Cu}, \mathrm{Cr}, \mathrm{Ni}$. With an advent of multidisciplinary studies, microbes have now entered the field of material science ${ }^{[17,18,19,20]}$. Metal accumulating bacteria are now used as source for production of metal nanostructured particles ${ }^{[21,22]}$. These biological materials can be used in their native form directly extracted from the living systems, or they can be processed after extraction and modified to their desired form. Earlier reports indicate the ability of strains of Bacillus subtilis to reduce $\mathrm{Au}^{3+}$ ions to produce octahedral gold nanoparticles ${ }^{[23]}$.

With these enumerable possibilities for application of microbes, nine bacterial isolates were screened out from different sites of ECW which can prove to be important from point of bioremediation and biotechnology.

\section{MATERIALS AND METHODS}

Isolation: The study was undertaken at different sites of ECW as shown in Table 1. With an aim to isolate protease secreting bacteria, solid milk medium containing $10 \%$ double toned milk, $0.3 \%$ yeast extract, $1.5 \%$ agar was used as the selective substrate. Luria Bertani (LB) broth containing tryptone $10 \mathrm{~g} \mathrm{~L}^{-1}$, yeast extract $5 \mathrm{~g} \mathrm{~L}^{-1}, \mathrm{NaCl} 5 \mathrm{~g} \mathrm{~L}^{-1}$ in double distilled water was used as medium for maintenance and other studies. The pure isolates were preserved at $-80^{\circ} \mathrm{C}$ in culture medium containing $70 \%(\mathrm{v} / \mathrm{v})$ glycerol.

Characterization of isolates: The pure isolates obtained were characterized in terms of their morphological, biochemical and molecular nature. The detailed protocols for the different areas of characterization are as reported by Nandy et al. ${ }^{[24]}$.

Metal tolerance: For metal uptake study, complex salts of metals were used. Ten different metals salts like $\mathrm{Al}\left(\mathrm{NO}_{3}\right)_{3} .9 \mathrm{H}_{2} \mathrm{O}, \quad \mathrm{CuSO}_{4} .5 \mathrm{H}_{2} \mathrm{O}, \quad \mathrm{AgCl}, \quad \mathrm{Pb}\left(\mathrm{NO}_{3}\right)$, $\mathrm{NiCl}_{2} \cdot 6 \mathrm{H}_{2} \mathrm{O}, \mathrm{HgCl}_{2}, \mathrm{CrO}_{3}, \mathrm{FeSO}_{4}, 7 \mathrm{H}_{2} \mathrm{O}, \mathrm{CoCl} .6 \mathrm{H}_{2} \mathrm{O}$ and $\mathrm{CdCl}_{3}$ were taken for study. Molar stock solutions of these salts were prepared and each of them was added as supplement in lower concentration to the LB medium which was seeded with $1 \%$ inoculum. For $\mathrm{AgCl}$, the saturated solution was used. The tolerance was checked on the basis of observation of growth by turbidimetric method within 12-48 $\mathrm{h}$. The minimum concentration of each metal added was $0.1 \mathrm{mM}$ and the concentration was gradually increased till Minimum Inhibitory Concentration (MIC) was achieved as visualized by cessation of growth. This tolerance was checked independently for all metals.

Quantification of metal accumulation: Post growth in highest metal concentration, cells were harvested by centrifugation and washed with $0.1 \mathrm{~N} \mathrm{HCl}$ thrice in order to remove all the particles adsorbed to the cell surface. This step ensures the removal of any adsorbed material so that only the intracellular accumulation of metal can be quantified. Post washing, the cell pellet was resuspended with Phosphate Buffer Saline (PBS) and the suspension was vacuum filtered. The filter paper containing the cell sample was dried and subjected to element analysis using EDXRF. A Jordan Valley EX-3600 EDXRF system was used in the present study. The details of the EDXRF system and the analysis procedure is as mentioned by Ray Chaudhuri et al.$^{[3]}$. 
Transmission electron microscopy: After the detection and quantification of intracellular metal, Transmission Electron Microscopy (TEM) of the cells were done in order to trace the exact location of metal inside the cell. Both normal and metal treated cells were harvested at a density of $10^{8}-10^{9}$ cells $\mathrm{mL}^{-1}$. The cell pellet was washed with PBS thrice followed by resuspension in $1 \mathrm{~mL}$ of fixative solution (2.5\% gluteraldehyde and $2 \%$ formaldehyde) and kept for $6 \mathrm{~h}$ at $4^{\circ} \mathrm{C}$. Post fixation, the fixative solution was removed by centrifugation and the cell pellet was washed with PBS five times, finally resuspended in $1 \mathrm{~mL}$ of sodium phosphate buffer and was analyzed by TEM. Microscopic imaging of whole cell as well as thin sections of cells were performed in a transmission electron microscope model number FEI Philips Morgagni $268 \mathrm{D}$ at $100 \mathrm{kV}$ acc. Voltage.

Scanning Electron Microscopy: Intracellular metal accumulation can lead to several changes in surface features of cells. To detect such changes the metal treated as well as untreated cells were analyzed by Scanning Electron Microscopy. SEM images have a characteristic three-dimensional appearance and are useful for judging the surface structure of the sample. The sample was fixed in the same way as done for TEM. The samples were then coated with a nanometerthick layer of gold after mounting them on studs following formation of smear on glass cover slips and then analyzed by SEM. Scanning Electron microscopy was performed at $30 \mathrm{kV}$ Acc. voltage on a SEM model number LEO 435 VP. Images were taken in 6000x and 9000x magnification.

\section{RESULTS AND DISCUSSION}

Isolation and characterization of strains: Nine pure isolates of protease secreting bacteria were obtained from six different sites of East Calcutta Wetland. The isolates were named according to their site of origin (Table 1). They were characterized on the basis of morphological and biochemical features. The gram nature and the results of enzymatic assays were shown in Table 1. Eight of the isolates were found to be catalase positive in nature while some of the isolates were found to produce oxidase and DNase enzyme. The presence of these enzymes can have importance in the survival of the bacteria as well as they can have biotechnological applications. The sensitivity to 18 different antibiotics tested were shown in Table 2. Five of the nine isolates were sensitive to neomycine, tetracycline and ciprofloxacin while three other were sensitive to at least two of them. Five of them were found sensitive to doxycycline and ampicillin. The antibiotic sensitivity profile of these isolates can provide serious insights to explore the molecular mechanisms of resistance and correlation

Table 1: Table indicating the site of isolation of the nine bacterial isolates along with their morphological, biochemical and molecular characterization. "+" denotes the enzyme secreting property of the isolate, "-" denotes the absence of enzyme production. RSC+ and $\mathrm{BW}+$ denotes the protease secreting characteristic of the isolates along with its site of origin. Cell Morph stands for cell morphology, Ac.No stands for GenBank Accession number of the 16S rRNA sequence. Green Zone is the part of the oldest dumping ground that has been converted to a region with dense vegetation more like the tropical forest ${ }^{[8]}$

\begin{tabular}{|c|c|c|c|c|c|c|c|c|c|}
\hline \multirow[b]{2}{*}{ Isolate } & \multirow[b]{2}{*}{$\begin{array}{l}\text { Site of } \\
\text { origin }\end{array}$} & \multicolumn{2}{|c|}{ Morphological characterization } & \multicolumn{3}{|c|}{ Biochemical characterization } & \multicolumn{3}{|c|}{ Molecular characterization } \\
\hline & & $\begin{array}{l}\text { Gram } \\
\text { nature }\end{array}$ & $\begin{array}{l}\text { Cell } \\
\text { morph }\end{array}$ & Lipase & Catalase & DNase & Oxidase & $\begin{array}{l}\text { Closest neighbor and } \\
\text { percentage similarity }\end{array}$ & Ac.No \\
\hline $\mathrm{C} 1$ & $\begin{array}{l}\text { Charak } \\
\text { danga Bheri }\end{array}$ & $\mathrm{Gm}+\mathrm{ve}$ & Short rods & - & + & + & + & $\begin{array}{l}\text { Pseudomonas } \\
\text { aeruginosa }(100 \%)\end{array}$ & - \\
\hline $\mathrm{C} 2$ & $\begin{array}{l}\text { Charak } \\
\text { danga Bheri }\end{array}$ & $\mathrm{Gm}+\mathrm{ve}$ & Bacilli & - & + & + & + & $\begin{array}{l}\text { Pseudomonas } \\
\text { aeruginosa }(100 \%)\end{array}$ & - \\
\hline $\mathrm{C} 4$ & $\begin{array}{l}\text { Charak } \\
\text { danga Bheri }\end{array}$ & $\mathrm{Gm}+\mathrm{ve}$ & Short rods & - & + & + & + & $\begin{array}{l}\text { Pseudomonas } \\
\text { aeruginosa }(100 \%)\end{array}$ & - \\
\hline F1 & Salt Lake & $\mathrm{Gm}+\mathrm{ve}$ & Long diplobacilli & - & + & - & - & $\begin{array}{l}\text { Bacillus } \\
\text { amyloliquefaciens } \\
(99.68 \%)\end{array}$ & EU006693 \\
\hline $\mathrm{F} 2$ & Salt Lake & $\mathrm{Gm}+\mathrm{ve}$ & Bacilli & - & + & - & - & $\begin{array}{l}\text { Bacillus subtilis } \\
\text { Subtilis }(99.94 \%)\end{array}$ & EU006694 \\
\hline F3 & Salt Lake & $\mathrm{Gm}+\mathrm{ve}$ & Long thin rods & - & + & - & - & $\begin{array}{l}\text { Bacillus subtilis } \\
\text { Subtilis }(99.94 \%)\end{array}$ & - \\
\hline GZ & Green Zone & Gm-ve & Bacilli & - & + & - & - & $\begin{array}{l}\text { Microbacterium } \\
\text { luteolum }(98.22 \%)\end{array}$ & EU006695 \\
\hline RSC+ & $\begin{array}{l}\text { Raw Sewage } \\
\text { Canal adjuscent } \\
\text { to Captain Bheri }\end{array}$ & $\mathrm{Gm}+\mathrm{ve}$ & $\begin{array}{l}\text { Cocci in } \\
\text { short chain }\end{array}$ & - & - & - & + & $\begin{array}{l}\text { Enterococcus } \\
\text { faecalis }(99.79 \%)\end{array}$ & EU006696 \\
\hline BW+ & $\begin{array}{l}\text { Captain } \\
\text { Bheri Water }\end{array}$ & $\mathrm{Gm}+\mathrm{ve}$ & Bacilli & - & + & - & - & Unidentified & - \\
\hline
\end{tabular}


Am. J. Biochem. \& Biotech., 4(3): 255-264, 2008

Table 2: Results of Antibiotic Sensitivity of the nine isolates using Muller Hinton Agar. The abbreviation of the antibiotics [Ampicillin(A), Cephadroxil(Cq), Chloramphenicol(C), Cloxacillin(Cx), Cephotaxime(Ce), Ceftazidime(Ca), Ciprofloxacin(Cf), Doxycycline Hydrochloride(Do), Gentamicin $(\mathrm{G})$, Metronidazole (Mt), Neomycin $(\mathrm{N})$, Norfloxacin $(\mathrm{Nx})$, Polymyxin $\mathrm{B}(\mathrm{Pb})$, Rifampicin $(\mathrm{R})$, Roxithromycin(Ro), Tetracycline(T), Trimethoprin (Tr), Vancomycin (Va)] with their respective concentration in mcg per disc is mentioned in the first and second row of the table, while the first column denotes the different strains. Here R denotes resistant, I denotes intermediate response and $\mathrm{S}$ denotes sensitive

\begin{tabular}{lllllllllllllllllll}
\hline Strain & $\mathrm{T}$ & $\mathrm{Cq}$ & $\mathrm{C}$ & $\mathrm{Cx}$ & $\mathrm{Pb}$ & $\mathrm{N}$ & $\mathrm{A}$ & $\mathrm{R}$ & $\mathrm{Cf}$ & $\mathrm{Ro}$ & $\mathrm{Do}$ & $\mathrm{Ce}$ & $\mathrm{Ca}$ & $\mathrm{Nx}$ & $\mathrm{G}$ & $\mathrm{Mt}$ & $\mathrm{Tr}$ & $\mathrm{Va}$ \\
Conc & 30 & 30 & 30 & 10 & 100 & 30 & 10 & 15 & 5 & 30 & 30 & 30 & 30 & 10 & 10 & 4 & 30 & 30 \\
\hline $\mathrm{C} 1$ & $\mathrm{~S}$ & $\mathrm{R}$ & $\mathrm{R}$ & $\mathrm{R}$ & $\mathrm{R}$ & $\mathrm{S}$ & $\mathrm{R}$ & $\mathrm{R}$ & $\mathrm{I}$ & $\mathrm{S}$ & $\mathrm{R}$ & $\mathrm{S}$ & $\mathrm{S}$ & $\mathrm{S}$ & $\mathrm{S}$ & $\mathrm{R}$ & $\mathrm{R}$ & $\mathrm{R}$ \\
$\mathrm{C} 2$ & $\mathrm{R}$ & $\mathrm{R}$ & $\mathrm{R}$ & $\mathrm{R}$ & $\mathrm{R}$ & $\mathrm{S}$ & $\mathrm{R}$ & $\mathrm{R}$ & $\mathrm{S}$ & $\mathrm{R}$ & $\mathrm{R}$ & $\mathrm{I}$ & $\mathrm{S}$ & $\mathrm{S}$ & $\mathrm{S}$ & $\mathrm{R}$ & $\mathrm{R}$ & $\mathrm{R}$ \\
$\mathrm{C} 4$ & $\mathrm{~S}$ & $\mathrm{R}$ & $\mathrm{R}$ & $\mathrm{R}$ & $\mathrm{R}$ & $\mathrm{S}$ & $\mathrm{R}$ & $\mathrm{R}$ & $\mathrm{S}$ & $\mathrm{R}$ & $\mathrm{R}$ & $\mathrm{S}$ & $\mathrm{S}$ & $\mathrm{S}$ & $\mathrm{S}$ & $\mathrm{R}$ & $\mathrm{R}$ & $\mathrm{R}$ \\
$\mathrm{F} 1$ & $\mathrm{~S}$ & $\mathrm{~S}$ & $\mathrm{~S}$ & $\mathrm{~S}$ & $\mathrm{R}$ & $\mathrm{I}$ & $\mathrm{S}$ & $\mathrm{R}$ & $\mathrm{S}$ & $\mathrm{S}$ & $\mathrm{S}$ & $\mathrm{S}$ & $\mathrm{S}$ & $\mathrm{S}$ & $\mathrm{S}$ & $\mathrm{R}$ & $\mathrm{R}$ & $\mathrm{R}$ \\
$\mathrm{F} 2$ & $\mathrm{~S}$ & $\mathrm{~S}$ & $\mathrm{~S}$ & $\mathrm{~S}$ & $\mathrm{R}$ & $\mathrm{S}$ & $\mathrm{S}$ & $\mathrm{R}$ & $\mathrm{S}$ & $\mathrm{R}$ & $\mathrm{S}$ & $\mathrm{S}$ & $\mathrm{S}$ & $\mathrm{S}$ & $\mathrm{S}$ & $\mathrm{R}$ & $\mathrm{R}$ & $\mathrm{R}$ \\
$\mathrm{F} 3$ & $\mathrm{~S}$ & $\mathrm{~S}$ & $\mathrm{R}$ & $\mathrm{S}$ & $\mathrm{R}$ & $\mathrm{S}$ & $\mathrm{S}$ & $\mathrm{S}$ & $\mathrm{S}$ & $\mathrm{S}$ & $\mathrm{S}$ & $\mathrm{R}$ & $\mathrm{S}$ & $\mathrm{S}$ & $\mathrm{S}$ & $\mathrm{R}$ & $\mathrm{R}$ & $\mathrm{R}$ \\
$\mathrm{GZ}$ & $\mathrm{S}$ & $\mathrm{I}$ & $\mathrm{S}$ & $\mathrm{R}$ & $\mathrm{R}$ & $\mathrm{S}$ & $\mathrm{S}$ & $\mathrm{R}$ & $\mathrm{S}$ & $\mathrm{S}$ & $\mathrm{S}$ & $\mathrm{R}$ & $\mathrm{S}$ & $\mathrm{S}$ & $\mathrm{S}$ & $\mathrm{R}$ & $\mathrm{R}$ & $\mathrm{R}$ \\
$\mathrm{RSC}+$ & $\mathrm{S}$ & $\mathrm{I}$ & $\mathrm{R}$ & $\mathrm{R}$ & $\mathrm{R}$ & $\mathrm{I}$ & $\mathrm{S}$ & $\mathrm{S}$ & $\mathrm{R}$ & $\mathrm{S}$ & $\mathrm{I}$ & $\mathrm{S}$ & $\mathrm{S}$ & $\mathrm{S}$ & $\mathrm{I}$ & $\mathrm{R}$ & $\mathrm{R}$ & $\mathrm{R}$ \\
$\mathrm{BW}+$ & $\mathrm{S}$ & $\mathrm{I}$ & $\mathrm{S}$ & $\mathrm{R}$ & $\mathrm{R}$ & $\mathrm{S}$ & $\mathrm{S}$ & $\mathrm{R}$ & $\mathrm{S}$ & $\mathrm{S}$ & $\mathrm{S}$ & $\mathrm{S}$ & $\mathrm{R}$ & $\mathrm{S}$ & $\mathrm{S}$ & $\mathrm{R}$ & $\mathrm{S}$ & $\mathrm{S}$ \\
\hline
\end{tabular}

between metal and antibiotic resistance. The purity of the extracellular enzyme was confirmed through the banding pattern of the coomassie stained $12 \%$ SDS PAGE gel (Fig. 1a). The gel shows multiple bands in all cases which could either be the different subunits of the protease in some case while in most of the cases those would be other secretory proteins released form the cell. The enzyme activity was monitored through gelatin zymography as described in the legend to Fig. 1b. The zymograph shows distinct activity with gelatin as substrate on a renatured SDS PAGE gel in case of $\mathrm{C} 2$ and $\mathrm{C} 4$. It is to be noted that the other isolates show activity on milk media plate (plate clearing activity) as well as on doing biochemical assay with hide powder azure (data not shown) but they fail to show activity on the zymograph. It could be due to couple of reasons like those enzymes loose their activity under denaturing condition and can not refold to its native confirmation on renaturation. It is also possible that these proteins need some cofactors which are getting displaced on PAGE and thus resulting in loss of activity. It is also possible that the enzyme is composed of multiple subunit of variable molecular weight which are getting separated on SDS PAGE and thus not showing activity. In order to confirm the exact reason for the lack of activity for the 6 isolates further experiments including native gel electrophoresis for zymography would be needed. Another point to be noted is that the prominent band in the coomassie stained SDS PAGE is not the band getting highlighted in the zymograph, thus the major protein in the extracellular supernatant is not the protease.

Molecular characterization was done on the basis of $16 \mathrm{SrDNA}$ sequences. Four novel sequences were obtained and submitted in GenBank (Table 1). The closest neighbor was predicted and the percentage of similarity with it is depicted in Table 1. The phylogenetic position were predicted using the neighbor joining method (Fig. 2). Isolate $\mathrm{BW}+$ is yet unidentified.

Metal tolerance: All the isolates were found to be tolerant to metals like $\mathrm{Ag}, \mathrm{Al}, \mathrm{Co}, \mathrm{Cu}, \mathrm{Cr}, \mathrm{Hg}, \mathrm{Ni}, \mathrm{Cd}$, $\mathrm{Fe}$ and $\mathrm{Pb}$ but to different extent. The phenomenon of metal tolerance depends on different pathways taken up by the cell. One is metabolism independent adsorption of metal to the cell surface and the other way can be metal uptake inside the cell with the expenditure of metabolic energy. The $0.1 \mathrm{~N} \mathrm{HCl}$ wash of the cell after growth in presence of metal ensures that adsorbed metal is removed. Thereafter EDXRF analysis indicates that maximum accumulation was found in case of $\mathrm{Pb}$ followed by $\mathrm{Cu}$ and $\mathrm{Cr}$ (data not shown). This finding is important from environmental perspective. These bacteria can be employed for up taking those metals from contaminated sites. $\mathrm{Pb}$ and $\mathrm{Cr}$ are increasingly found in the discharge from industries involved in production of dye and paint, electroplating, pharmaceutics, organic chemicals, etc.

The ability of these bacteria is not just limited to metal accumulation. A vast application of these in material science can be predicted after Transmission Electron Microscopic analysis revealed the interior of metal treated cells. Some cells upon treatment with metal, uptake and accumulate it through and through (Fig. 3a, b) and in some others, metal is accumulated in form of patches (Fig. 3c). This distribution is independent of molecular nature of isolate, type of metal and quantity of metal accumulation.

But the most important finding with these metal treated isolates is the generation of nanostructured particles inside the cells (Fig. 3d, e, f, g, h). Almost all the isolates were found to generate these metal particles with $\mathrm{Pb}$ and $\mathrm{Hg}$ treatment. The number of nanoparticles/cell varies from isolate to isolate. In isolate $\mathrm{C} 1$, nanoparticles are found in presence of $\mathrm{Pb}$, 


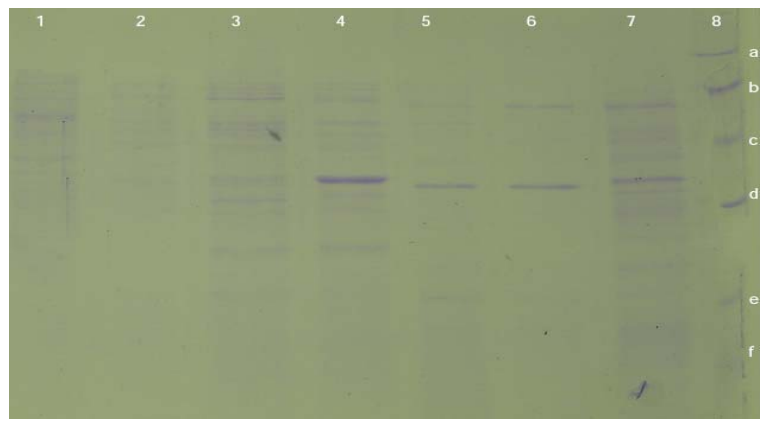

Fig. 1a: A $12 \%$ denaturing polyacrylamide gel showing the results of analysis of crude supernatant from nine isolates. The gel was run on a BIORAD Mini PROTEAN 3 System for $60 \mathrm{~min}$ at $45 \mathrm{~mA}$ (constant current). Loading sequence is as follows: Lane 1-F3, Lane 2RSC+, Lane 3-F2, Lane 4-F1, Lane 5-C4, Lane 6-C2, Lane 7-C1, Lane 8-Protein Marker (Cat No. PMW-ss, Bangalore Genei, India). Each lane from 1 to 7 was loaded with $25 \mu \mathrm{g}$ of protein sample as determined through standard Lowry method. Lane 8 was loaded with $6 \mu \mathrm{g}$ of marker. The size range of the bands in the marker lane is as follows: $a=97.4 \mathrm{kD}$, $\mathrm{b}=66 \mathrm{kD}, \mathrm{c}=43 \mathrm{kD}, \mathrm{d}=29 \mathrm{kD}, \mathrm{e}=18.4 \mathrm{kD}$, $\mathrm{f}=6.5 \mathrm{kD}$

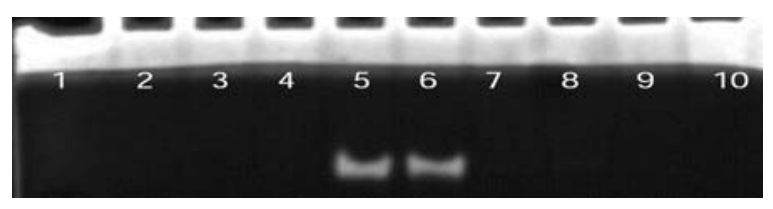

Fig. 1b: Protease Zymograph of $12 \%$ polyacrylamide. The gel was run on a BIORAD Mini PROTEAN 3 System for $60 \mathrm{~min}$ at $45 \mathrm{~mA}$ (constant current). Twelve percent SDS gel containing $1 \%$ gelatin was used for analysis. $25 \mu \mathrm{g}$ of protein loaded in each lane. After run the gel was renatured by washing with 0.04 (M) Tris $\mathrm{HCl}$ (pH-7.6) for overnight with a periodic buffer change. After overnight renaturation the gel was stained with coomassie blue. Lanes showing protease activity show clearing zone corresponding to the active protease band. Loading was done in following order: Lane 1-F3, Lane 2-F2, Lane 3-F1, Lane 4-C1, Lane 5-C2, Lane 6-C4, Lane 7$\mathrm{BW}+$, Lane 8-GZ, Lane 9- RCS+, Lane 10marker (same as the one used in Fig 1a). The size of active band of $\mathrm{C} 2$ and $\mathrm{C} 4$ lies between 97.4 and $66 \mathrm{kD}$

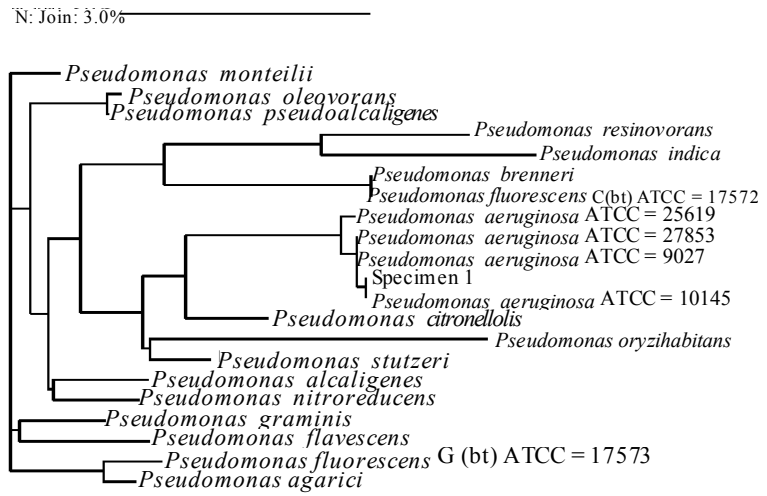

Fig. 2a: Tree of 16S rRNA based phylogenetic analysis of isolate $\mathrm{C} 1$ constructed using neighbour joining method

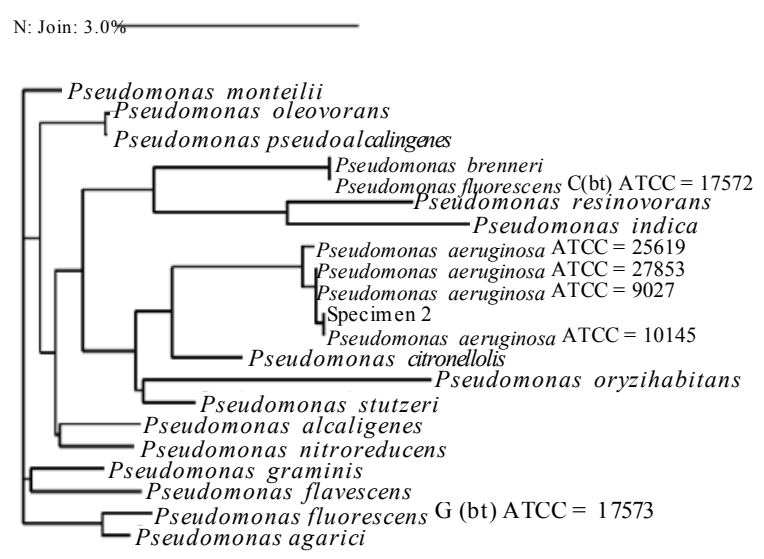

Fig 2b: Tree of 16S rRNA based phylogenetic analysis of isolate $\mathrm{C} 2$ constructed using neighbour joining method

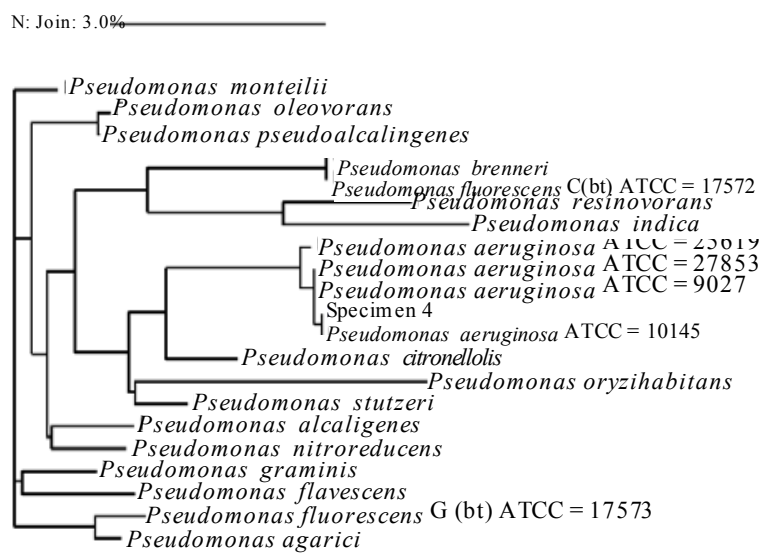

Fig 2c: Tree of 16S rRNA based phylogenetic alanysis of isolate $\mathrm{C} 4$ constructed using neighbour joining method 
Am. J. Biochem. \& Biotech., 4(3): 255-264, 2008

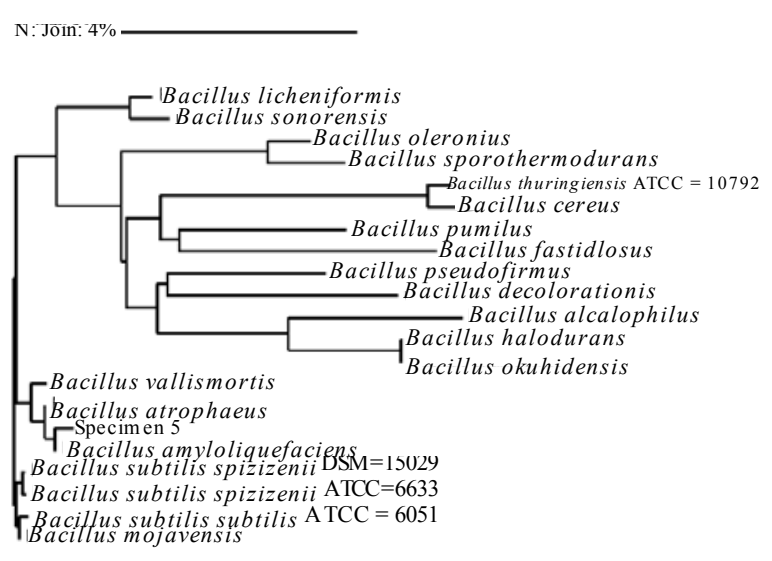

Fig 2d: Tree of 16S rRNA based phylogenetic alanysis of isolate F1 constructed using neighbour joining method

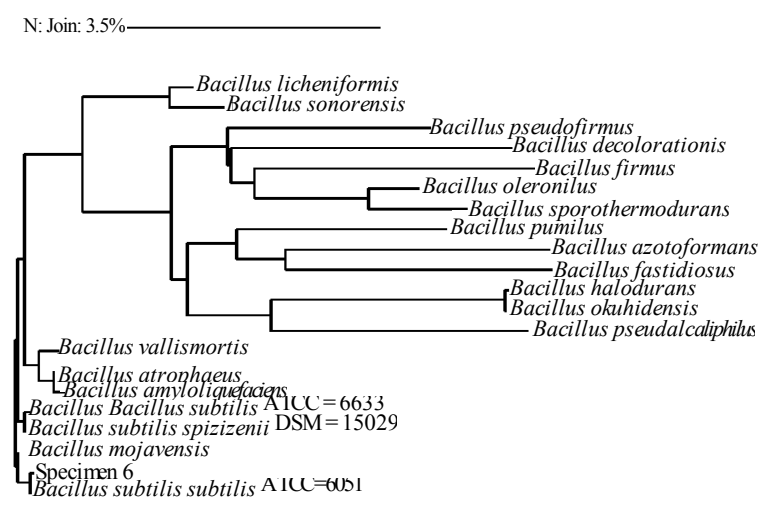

Fig 2e: Tree of 16S rRNA based phylogenetic alanysis of isolate F2 constructed using neighbour joining method

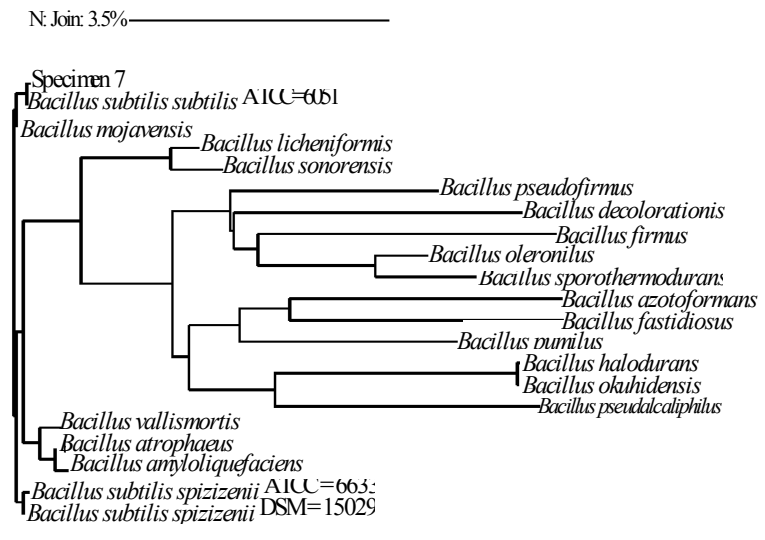

Fig. 2f: Tree of 16S rRNA based phylogenetic alanysis of isolate F3 constructed using neighbour joining method

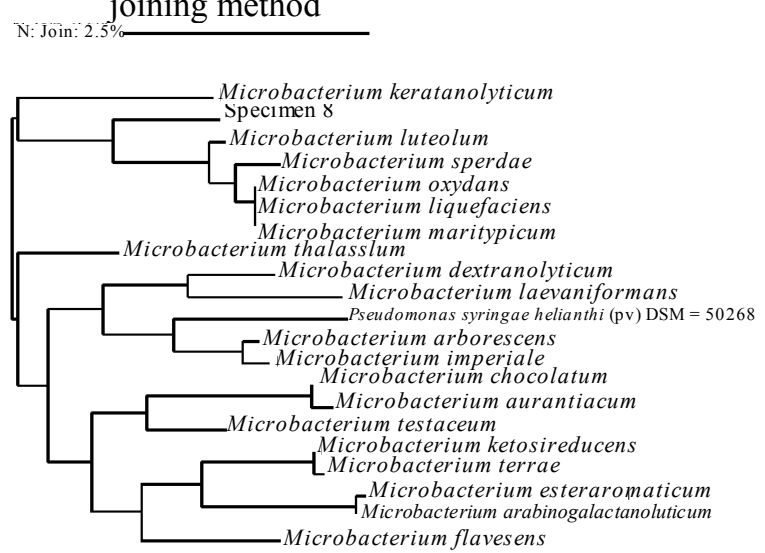

Fig. 2g: Tree of 16S rRNA based phylogenetic alanysis of isolate GZ constructed using neighbour joining method

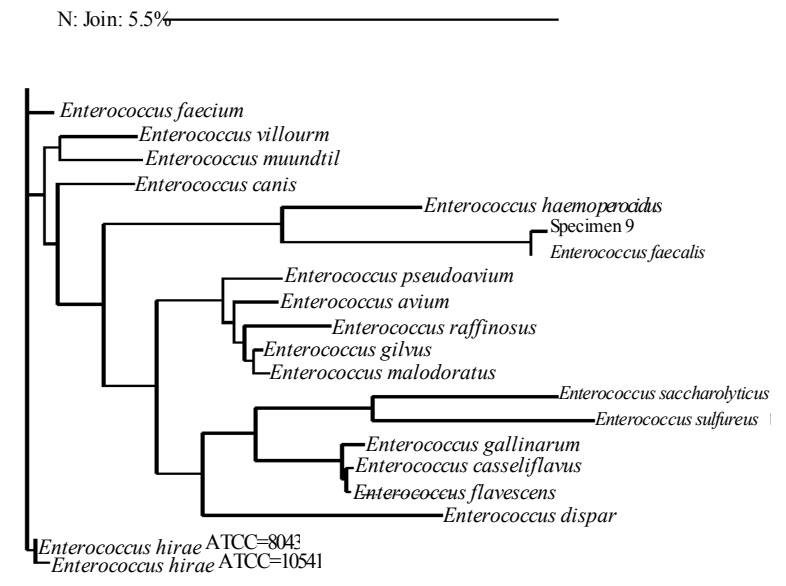

Fig. 2h: Tree of $16 \mathrm{~S}$ rRNA based phylogenetic alanysis of isolate RSC + constructed using neighbour joining method 


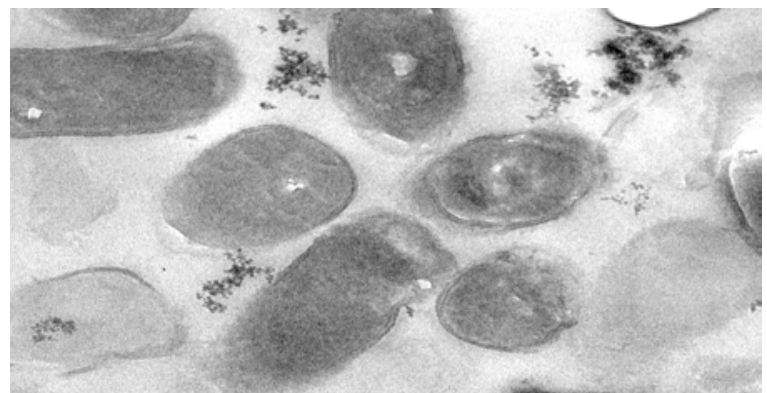

(a)

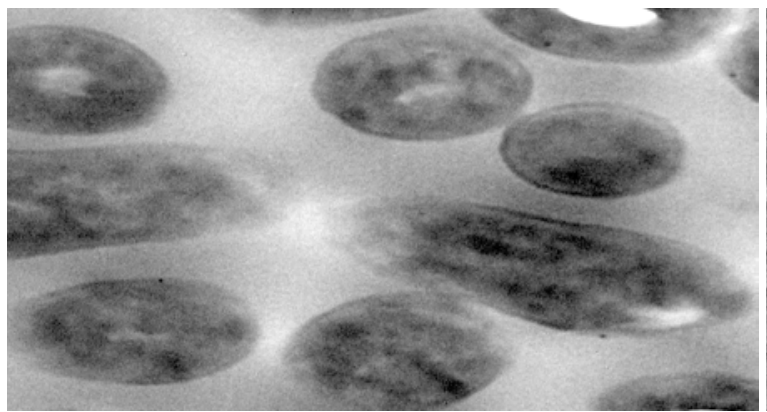

(c)

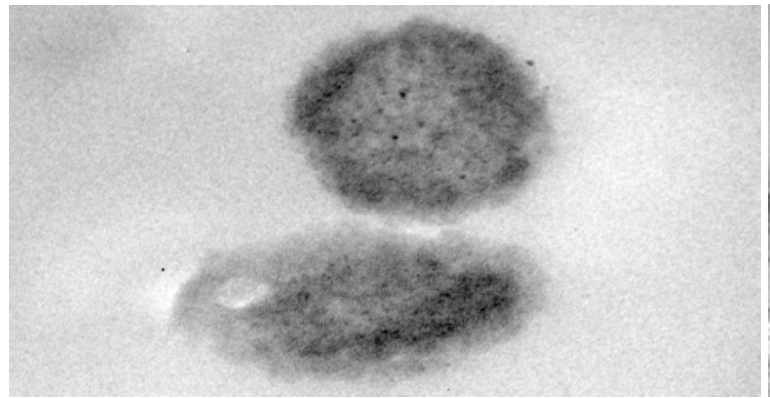

(e)

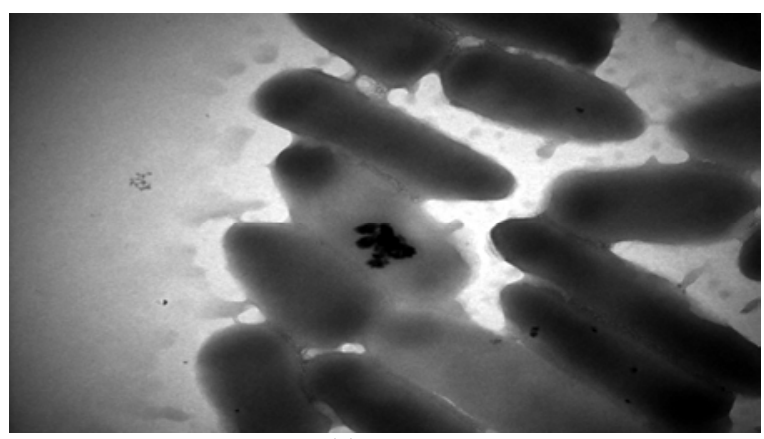

(g)

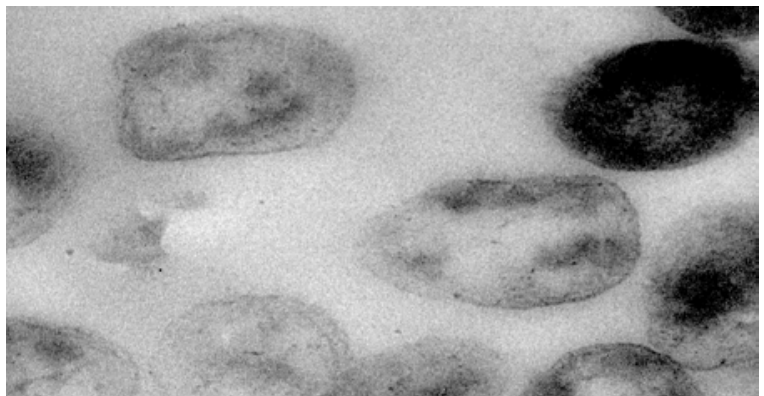

(b)

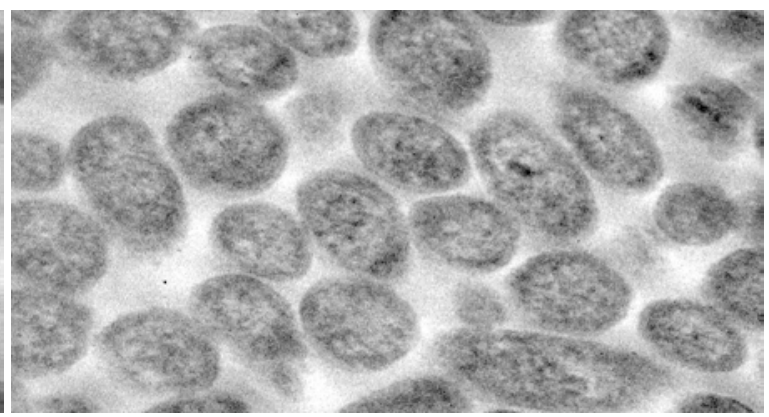

(d)

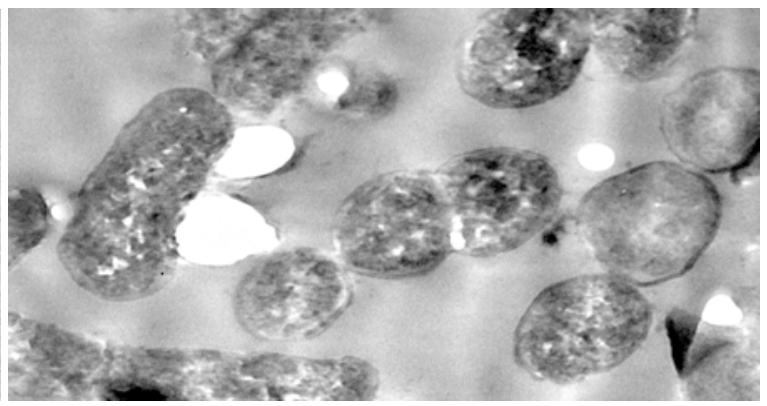

(f)

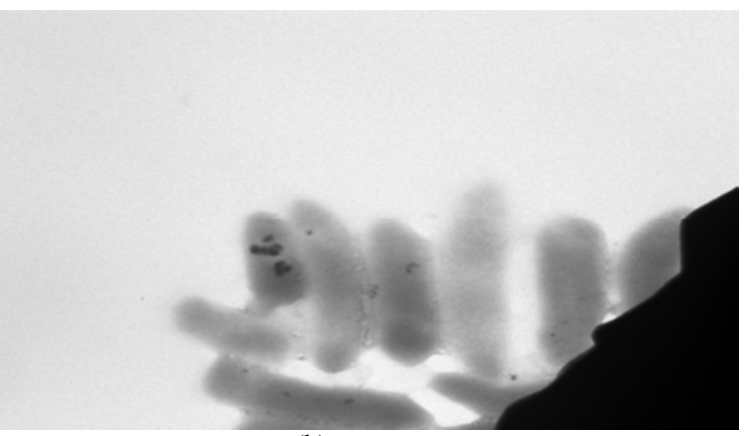

(h)

Fig. 3: Transmission Electron Micrographs depicting the accumulation of metal and generation of nanoparticles inside the bacterial cells on metal treatment. (a): Isolate $\mathrm{C} 4$ treated with $\mathrm{Pb}$ salt, (b): Isolate $\mathrm{C} 4$ treated with Cd salt, (c): Isolate $\mathrm{RSC}+$ in presence of $\mathrm{Cr}$ salt, (d): Isolate $\mathrm{C} 1$ treated with $\mathrm{Cr}$ salt, (e): Isolate $\mathrm{C} 2$ in presence of $\mathrm{Hg}$ salt, (f): Isolate F3 treated with Ni salt and (g): As well as (h): Depicts isolate $\mathrm{C} 1$ treated with $\mathrm{Pb}$ and viewed at different angles 


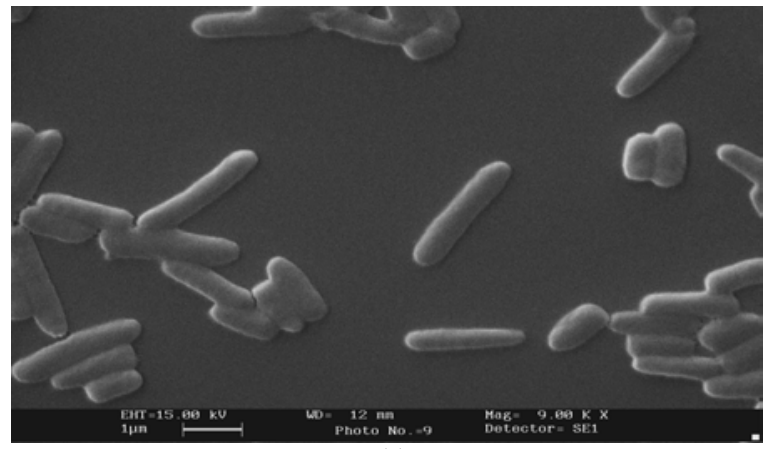

(a)

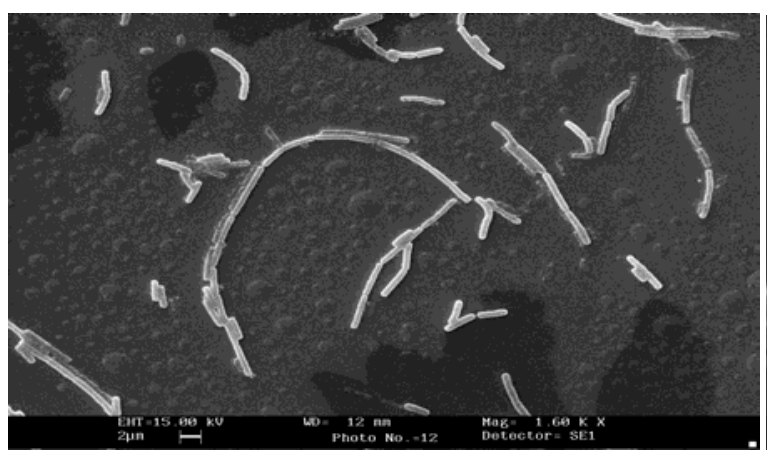

(c)

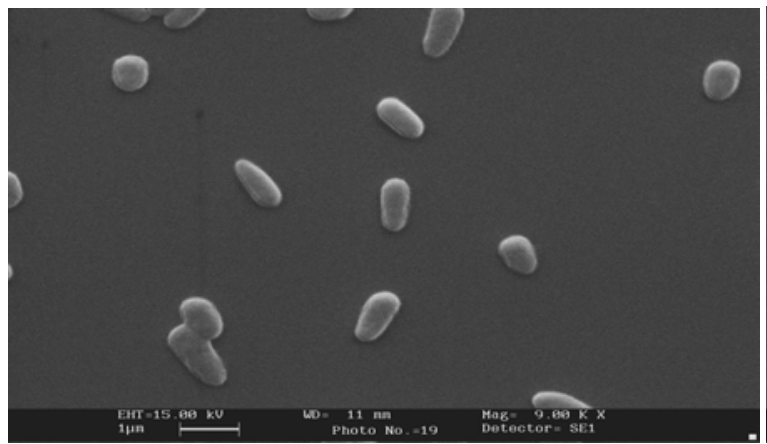

(e)

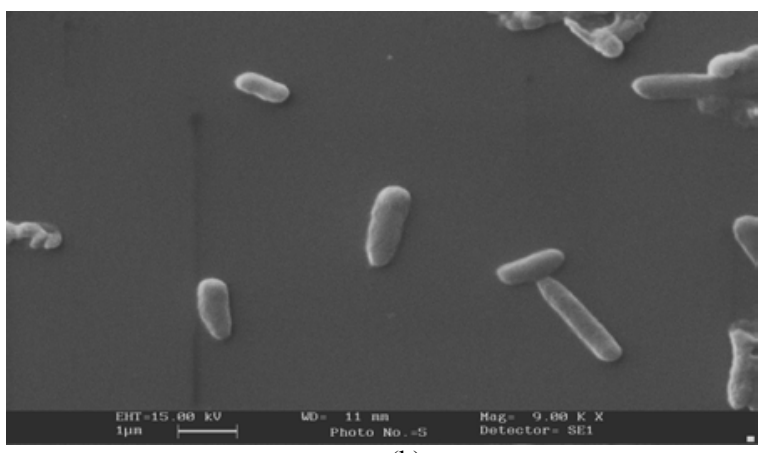

(b)

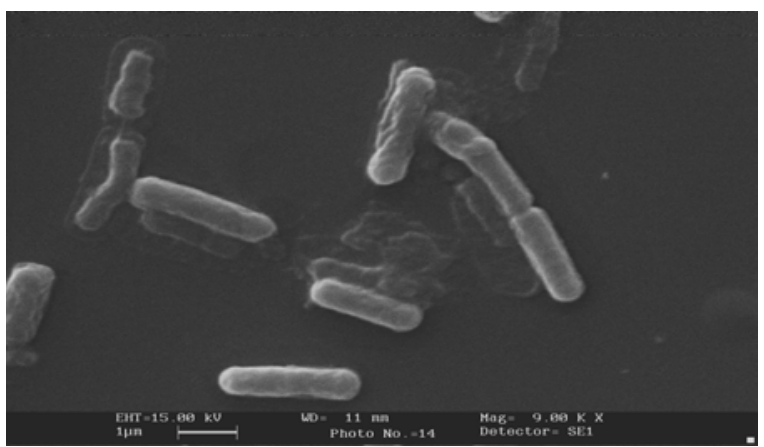

(d)

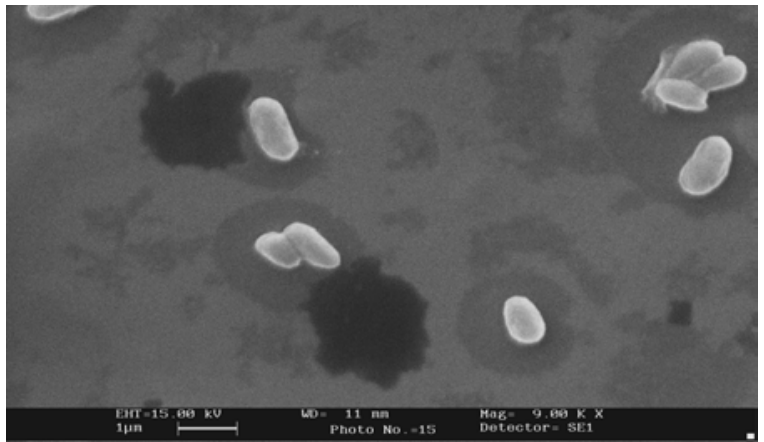

(f)

Fig. 4: Scanning Electron Micrographs depicting the effect of metal on the cell morphology and dimensions of isolates in absence and presence of metal treatment. (a): Isolate $\mathrm{C} 1$ untreated, (b): $\mathrm{C} 1$ treated with $\mathrm{Pb}$ salt, (c): Isolate F1 without metal treatment, (d): F1 treated with Cr salt, (e): isolate $\mathrm{C} 2$ untreated, (f): $\mathrm{C} 2$ treated with Ni salt

$\mathrm{Ni}, \mathrm{Al}, \mathrm{Cr}, \mathrm{Cd}$ and $\mathrm{Hg}$. For $\mathrm{Pb}$ the number of nanoparticles/cell and size of particles were observed to be 1-8 and 62-77 $\mathrm{nm}$ respectively; for $\mathrm{Ni}$ 10-50 nanoparticles/cell with 11-38 nm size range; for $\mathrm{Al}, 5-20$ nanopaticles/cell with size range of $12-40 \mathrm{~nm}$; for Cr, 1-7 particles/cell with size range of $25-41 \mathrm{~nm}$; for $\mathrm{Cd}, 1-8$ particles/cell with size varying from 19-26 nm and for Hg, 8-15 nanoparticles/cell with $11-21 \mathrm{~nm}$ size range were observed. In isolate $\mathrm{C} 2$ about 50 nanoparicles/cell were found with $\mathrm{Pb}$ treatment and the size range of the particles vary from $10-16 \mathrm{~nm}$; for Cr, 2-10 particles/cell with size range of $30-92 \mathrm{~nm}$; for Cd 53 particle/cell were seen and size range of particle lies between 12-24 $\mathrm{nm}$ and with $\mathrm{Hg}$ treatment the number of particles/cell was 16-26 with size range of 9.3-34 nm. In case of isolate $\mathrm{C} 4$ about 20 nanoparticles/cell were found with Ni treatment with size between 3.5-19 $\mathrm{nm}$; for $\mathrm{Cr}, 2-15$ particles of 44-123 nm and for Cd, 5-28 particles of 9.4-24 nm were observed. For isolate F1 about 1-10 particles of 
78-92 $\mathrm{nm}$ in case of $\mathrm{Pb}$ treatment, $1-3$ particle/cell of 24-46 nm for Cr, about 2 particles per cell of $31 \mathrm{~nm}$ for $\mathrm{Hg}$ was observed. Isolate $\mathrm{F} 2$ showed 1-5 particles/cell of 47-58 nm for $\mathrm{Cr}$ and about 100 particles of $19-73 \mathrm{~nm}$ for $\mathrm{Hg}$. Transmission electron micrographs of the cells of F3 showed 5-7 nanopaticles of 55-95 nm in presence of $\mathrm{Pb}, 1-8$ particles/cell of 71-56 $\mathrm{nm}$ in presence of $\mathrm{Ni}$, 8-32 particles/cell of 12-2 $0 \mathrm{~nm}$ in presence of $\mathrm{Cd}$ and 1-3 particles/cell of 17-24 $\mathrm{nm}$ in presence of $\mathrm{Hg}$. Isolate $\mathrm{RSC}+$ showed generation of nanoparticles in presence of $\mathrm{Cu}, \mathrm{Cd}$ and $\mathrm{Hg}$. For $\mathrm{Cu}$ number of particles/cell and size range was 2 and $8.8-19 \mathrm{~nm}$ respectively, for Cd 1-5 particles/cell and 16-60 $\mathrm{nm}$ respectively and for $\mathrm{Hg} \mathrm{8-30} \mathrm{particles/cell} \mathrm{of} \mathrm{7.7-24} \mathrm{nm} \mathrm{sized} \mathrm{were} \mathrm{detected.}$ In isolate $\mathrm{GZ}, \mathrm{Pb}$ treatment produced about 6-15 particle/cell with size range of $10-11 \mathrm{~nm}$, for Cr 2 particles/cell of 90-108nm, for Hg 3 particles of $14-30 \mathrm{~nm}$ and for $\mathrm{Cu}$ about 1 particle/cell of 12-16 nm were observed. Isolate $\mathrm{BW}+$ showed nanopartcles in presence of Cd only. The number of particle/cell was $1-25$ and the size range was 10-54 nm. From the above results it is evident that in most of the isolates, in presence of $\mathrm{Pb}$ the number of nanoparticles/cell is highest as compared to other metal treatment. This result is at par with the EDXRF finding reported elsewhere stating maximum accumulation in case of $\mathrm{Pb}$. Similarly the size of the particle of a particular metal varies among the isolates. $\mathrm{The} \mathrm{Pb}$ and $\mathrm{Cr}$ particles are found to be relatively larger than others. This is in accordance with the metal accumulating efficiency of the bacteria as evident from the EDXRF analysis. In case of isolate $\mathrm{C} 1$ treated with $\mathrm{Pb}$, distinct nanoparticles were confirmed on angular tilting of the specimen stage during Transmission Electron Microscopy. This property of metal particle generation enables the bacteria to work as a living factory and as an inexpensive system to produce metal particles which have a strong application in the field of material science.

Intracellular metal accumulation was evident from EDXRF analysis followed by Transmission Electron Microscopy. This phenomenon can lead to several alterations in surface features of the cell. Metal uptake by cells can induce different response mechanisms such as induction of molecules like siderophores, metallothioneins. The effect of metals on cell morphology was demonstrated through Scanning Electron Microscopy. Distinct changes in cell size and surface features were observed for metal treated cells when compared with normal cells. Two distinct phenomenon were the shortening and thickening of the cells in presence of metals (Fig. 4a, b, c, d). The possible explanation for this is that a cell can't continuously go on accumulating beyond a limit and somehow the metabolic process is stunted in order to prevent further uptake. Another distinct observation in most of the cells is appearance of a woolly coat around the outer surface (Fig. 4e, f) which can possibly be extrapolysaccharide secreted by the cell which can reduce the surface area of contact between the cell and metal and thereby prevent further uptake. Another mechanism that also operates in some cases (not observed here) is the elongation of the cells which is observed when the cells increase the surface area to facilitate further accumulation of the metal inside itself.

\section{CONCLUSION}

Among various outcomes of the study, important aspect is the metal accumulating ability of these isolates which can be applied in removal and recovery of metals. These studies can further direct towards designing of a bioremedial package for application purpose. The nine isolates, all with significant metal up taking ability can be either used as pure isolates or as a mixed consortium to act efficiently in lesser time. The metal accumulation and nanoparticle generation by the cell can be further explored at a molecular level. This can further help in genetic manipulation for more efficiency and practical purpose.

\section{ACKNOWLEDGEMENT}

The authors would like to acknowledge the financial support of Department of Science and Technology, India, Department of Biotechnology, India; Inter University Consortium Calcutta Centre and Board of Research in Nuclear Sciences, Department of Atomic Energy, India. They would thank West Bengal University of Technology for providing the computational as well as Bioinormatics Infrastructure Facility (DBT, GOI supported). They would also like to thank Dr. M Sudarshan of UGC-DAE Consortium for Scientific Research, Calcutta Centre for providing for EDXRF analysis and Dr Atanu Basu of National Institute of Virology, Pune, India for the Transmission Electron Microscopy. The authors would also like to thank Mr Soumen Roy for his assistance.

\section{REFERENCES}

1. Ray Chaudhuri, S., M. Mishra, P. Nandy and A.R. Thakur, 2008. Waste management: A case study of ongoing traditional practices at East Calcutta Wetland. Am. J. Agric. Biol. Sci., 3: 315-320. 
2. Ray Chaudhuri, S., M. Mishra, S. Salodkar, M. Sudarshan and A.R. Thakur, 2008 Traditional aquaculture practice at east calcutta wetland: The Safety Assessment. Am. J. Environ. Sci., 4: 140-144.

3. Ray Chaudhuri, S., S. Salodkar, M. Sudarshan and A.R. Thakur, 2007. Integrated Resource Recovery at East Calcutta Wetland-how safe is these? Int. J. Agric. Biol. Sci., 2: 75-80.

4. Olguin, E.J. and E. Hurnandoz, 1998. Round table on municipal water. Vancouver, Canada.

5. Prasad, B.B. and V.C. Pandey, 2000. Separation and preconcentration of cobalt and cadmium ions from multielemental solutions using Nostoc muscorum based biosorbents. World J. Microbiol. Biotechnol., 16: 819-827.

6. Pradhan, A., P. Bhaumik, S. Das, M. Mishra, S. Khanam, B. Amin Hoque, I. Mukherjee, A.R. Thakur and S. Ray Chaudhuri, 2008, Phytoplankton diversity as indicator of water quality for fish cultivation. Am. J. Environ. Sci., 4 (4): 271-276.

7. Ray Chaudhuri, S., S. Salodkar, M. Sudarshan, I. Mukherjee and A.R. Thakur, Role of water hyacinth mediated phytoremediation in waste water purification at east calcutta wetland. Environ. Sci., (Accepted).

8. Raychaudhuri, S. and A.R. Thakur, 2006. Microbial genetic resource mapping of East Calcutta Wetland. Curr Sci., 91: 212-217.

9. Georgalaki, M.D., E.V. Berghe, D. Kritikos, B. Devreese, J.V. Beeumen, G. Kalantzopoulos, L.D Vuyst and E. Tsakalidou, 2002. Macedocin, a Food-Grade Lantibiotic Produced by Streptococcus macedonicus ACA-DC 1998. Appl. Environ. Microbiol., 68: 5891-5903.

10. Rao, M.B., A.M. Tanksale, M.S. Ghatge and V.V. Deshpande, 1998. Molecular and biotechnological aspects of microbial proteases. Microbiol. Molecular Biol. Rev., 62: 597-635.

11. Guzzo, J., J.M. Pages, F. Duong, A. Lazdunski and M. Murgier, 1991. Pseudomonas aeruginosa alkaline protease: Evidence for secretion genes and study of secretion mechanism. J. Bacteriol., 173 (17): 5290-5297.

12. Gerze, A., D. Omay and Y. Guvenilir, 2005. Partial purification and characterization of protease enzyme from Bacillus subtilis megatherium. Applied Biochem. Biotechnol., 121 (1-3): 335-346.
13. Vidali, M., 2001. Bioremediation. An overview. Pure Appl. Chem., 73 (7): 1163-1172.

14. Lloyd, J.R. and D.R. Lovely, 2001. Microbial detoxification of metals and radionuclides. Curr. Opin. Biotechnol., 12: 248-253.

15. Gadd, G.M., 2000. bioremedial potential of microbial mechanisms of metal mobilization and immobilization. Curr. Opin. Biotechnol., 11:271-279.

16. Malekzadeh, F., A. Farazmand, H. Ghafourian, M. Shahamat, M. Levin and R.R. Colwell, 2002. Uranium accumulation by a bacterium isolated from electroplating effluent. World J. Microbiol. Biotechnol., 18 (4): 295-302.

17. Nakajima, A. and T. Sakaguchi, 1986. Selective accumulation of heavy metals by microorganisms. Appl. Microbiol. Biotechnol. , 24: 59-64.

18. Pümpel, T. and F. Schinner, 1986. Silver tolerance and silver accumulation of microorganisms from soil materials of a silver mine. Appl. Microbiol. Biotechnol., 24: 244-247.

19. Goddard, P.A. and A.T. Bull, 1989. The isolation and characterisation of bacteria capable of accumulating silver. Appl. Microbiol. Biotechnol., 31: 308-313.

20. Mengoni, A., R. Barzanti, C. Gonnelli, R. Gabbrielli and M. Bazzicalopo, 2001. Characterization of nickel-resistant bacteria isolated from serpentine soil. Environ. Microbiol., 3: 691-698.

21. Klaus-Joerger, T., R. Joerger, E. Olsson and C.G. Granqvist, 2001. Bacteria as workers in the living factory: Metal-accumulating bacteria and their potential for materials science. Trends Biotechnol., 19: 15-20.

22. 16 Salata, O.V., 2004. Applications of nanoparticles in biology and medicines. $J$. Nanobiotechnol., 2 (3).

23. Mandal, D., M.E. Bolander, D. Mukhopadhyay, G. Sarkar and P. Mukherjee, 2006. The use of microorganisms for the formation of metal nanoparticles and their application. Appl. Microbiol. Biotechnol., 69: 485-492.

24. Nandy, P., A.R. Thakur and S. Ray Chaudhuri, 2007. Characterization of bacterial strains isolated through microbial profiling of urine samples. On. J. Biol. Sci., 7(1): 44-51. 